\title{
To the study of arthropods of Tavrida Cave, Crimea
}

\author{
I.S. Turbanov ${ }^{1,2}$, A.A. Nadolny ${ }^{3}$, A.A. Turbanova ${ }^{1,4}$ \\ ${ }^{I}$ I.D. Papanin Institute of Biology of Inland Waters of RAS, Borok, Yaroslavl Region, Russia. \\ E-mail:turba13@mail.ru \\ ${ }^{2}$ Cherepovets State University, Cherepovets, Vologda Region, Russia. \\ ${ }^{3}$ A.O. Kovalevsky Institute of Biology of the Southern Seas of RAS, Sevastopol, Russia. \\ E-mail: nadolnyanton@mail.ru \\ ${ }^{4}$ A.N. Severtsov Institute of Ecology and Evolution of RAS, Moscow, Russia. \\ E-mail:nastenkadolce@mail.ru
}

ABSTRACT. Preliminary results of studying the biota of the recently discovered Tavrida Cave (Foothill Crimea) are presented. By now, six species of arthropods (Arthropoda) have been identified, i.e. one species of spiders (Aranei), one species of diplura (Diplura), two species of springtails (Collembola) and two species of flies (Diptera). The obtained results indicate the relative youth of the recent fauna of Tavrida Cave, despite Eopleistocene age cave, and have a significant faunal value, since a number of discovered species are specified for the first time for the Crimea and Russia. For the troglobiont diplura Campodea (Dicampa) taurica, discovered in Tavrida Cave, a probable scenario of its penetration into the karst cavities of the Crimea in connection with global climate changes in the Late Pleistocene time is presented. However, all other found species are most likely to have entered Tavrida Cave at the present time, after its opening as a result of road construction work.

How to site this article: Turbanov I.S., Nadolny A.A., Turbanova A.A. 2021. To the study of arthropods of Tavrida Cave, Crimea // Invert. Zool. Vol.18. No.2. P.177-185. doi: 10.15298/invertzool.18.2.08

KEY WORDS: fauna, Tavrida Cave, troglobiont, troglophile, subroglophile, Crimea.

\section{К изучению членистоногих пещеры Таврида, Крым}

\section{И.С. Турбанов ${ }^{1,2}$, А.А. Надольный ${ }^{3}$ А.А. Турбанова ${ }^{1,4}$}

\footnotetext{
${ }^{1}$ Институт биологии внутренних вод им. И.Д. Папанина РАН, Борок, Ярославская обл., Pосcия.E-mail: turba13@mail.ru

2 Череповеикий государственный университет, Череповец, Вологодская обл., Россия.

${ }^{3}$ Институт биологии южных морей им. А.О. Ковалевского РАН, Севастополь, Россия. E-mail:nadolnyanton@mail.ru

${ }^{4}$ Институт проблем экологии и эволючии им. А.Н. Северцова РАН, Москва, Россия.

E-mail: nastenkadolce@mail.ru
}

РЕЗЮМЕ. Представлены предварительные результаты изучения биоты недавно открытой пещеры Таврида (Предгорный Крым). На данный момент выявлено шесть видов членистоногих (Arthropoda) - один вид пауков (Aranei), один вид двухвосток (Diplura), два вида коллембол (Collembola) и два вида двукрылых (Diptera). Полученные результаты говорят о сравнительной молодости рецентной фауны пещеры Таврида, несмотря на эоплейстоценовый возраст пещеры, и имеют значительную 
фаунистическую ценность, т.к. ряд обнаруженных видов впервые указывается для Крыма и России. Для троглобионтной двухвостки Campodea (Dicampa) taurica, обнаруженной в пещере Таврида, представлен вероятный сценарий её проникновения в карстовые полости Крыма в связи с глобальными климатическими изменениями в позднеплейстоценовое время. Однако все остальные обнаруженные виды, вероятнее всего, проникли в пещеру Таврида в настоящее время, после её вскрытия в результате строительных дорожных работ.

Как цитировать эту статью: Turbanov I.S., Nadolny A.A., Turbanova A.A. 2021. To the study of arthropods of Tavrida Cave, Crimea // Invert. Zool. Vol.18. No.2. P.177-185. doi: 10.15298/invertzool.18.2.08

КЛЮЧЕВЫЕ СЛОВА: фауна, пещера Таврида, троглобионт, троглофил, субтроглофил, Крым.

\section{Introduction}

Tavrida Cave was opened in June 2018 during the construction of Tavrida highway. It is located near Zuya Village (Belogorsky Distr., Crimea). In accordance with the karstological zoning of the Crimea, Tavrida Cave belongs to the speleological region of the Inner Ridge, Simferopol karst region (Vakhrushev, 2009). The cavity belongs to the labyrinth type, has a length of $1300 \mathrm{~m}$ with an amplitude of $18 \mathrm{~m}$. The cave lies in the Eocene limestone. By its genesis Tavrida Cave is a relict hypogenic karst system (Amelichev et al., 2018, 2019).

A rich Eopleistocene taphocenosis of vertebrates was found in Tavrida Cave, the taxonomic composition of which allows us to date the bone deposits of the remains corresponding to the Late Villafrancian of Western Europe (zones MQ18-MQ19) and the Psekup (= Odessa) faunal complex of Russia, and has an age of about 1.8-1.5 million years (Lopatin et al., 2019). At the same time, the formation of the bulk of the karst cavities of the Crimea occurred much later, in the Middle and Late Pleistocene (Klimchouk et al., 2009). The Eopleistocene age and significant geological isolation of Tavrida Cave suggest the presence of relict elements of preGlacial times in its fauna. This hypothesis prompted us to conduct biospeleological studies in the cave under discussion.

On September 25, 2018, we made an inspection of Tavrida Cave in order to collect and study its biota. However, long-term visual searching of animals did not bring results. Our colleague, G.A. Prokopov (Simferopol), examined the cave in early July 2018 and also found no animals (personal communication). This case forced us to make temporary stations with baits to attract cave animals.

\section{Materials and methods}

In order to attract invertebrates, we have made some temporary biospeleological stations in Tavrida Cave, consisting of baits laid out in the cave, i.e. pieces of hard cheese and dried sausage, peeled boiled chicken eggs. The use of such baits makes it possible to attract invertebrates under conditions of limited trophic resources and almost complete absence of allochthonous organic matter. The exposure time of the baits was 31 days - from September 28 to October 29, 2018. In total, seven points (stations) with baits were placed within the cave, the scheme of their location is shown in Fig. 1.

The collection of material at temporary biospeleological stations was carried out manually, directly from the baits (with tweezers) and fixed in $96 \%$ alcohol. The smallest and most delicate invertebrates (Collembola, Diplura) were collected using an exhauster (suction device), also with subsequent fixation in $96 \%$ ethyl alcohol. The photos of living arthropods in the cave were taken with a digital camera Ricoh WG-4 (Ricoh Company Ltd, Japan). 


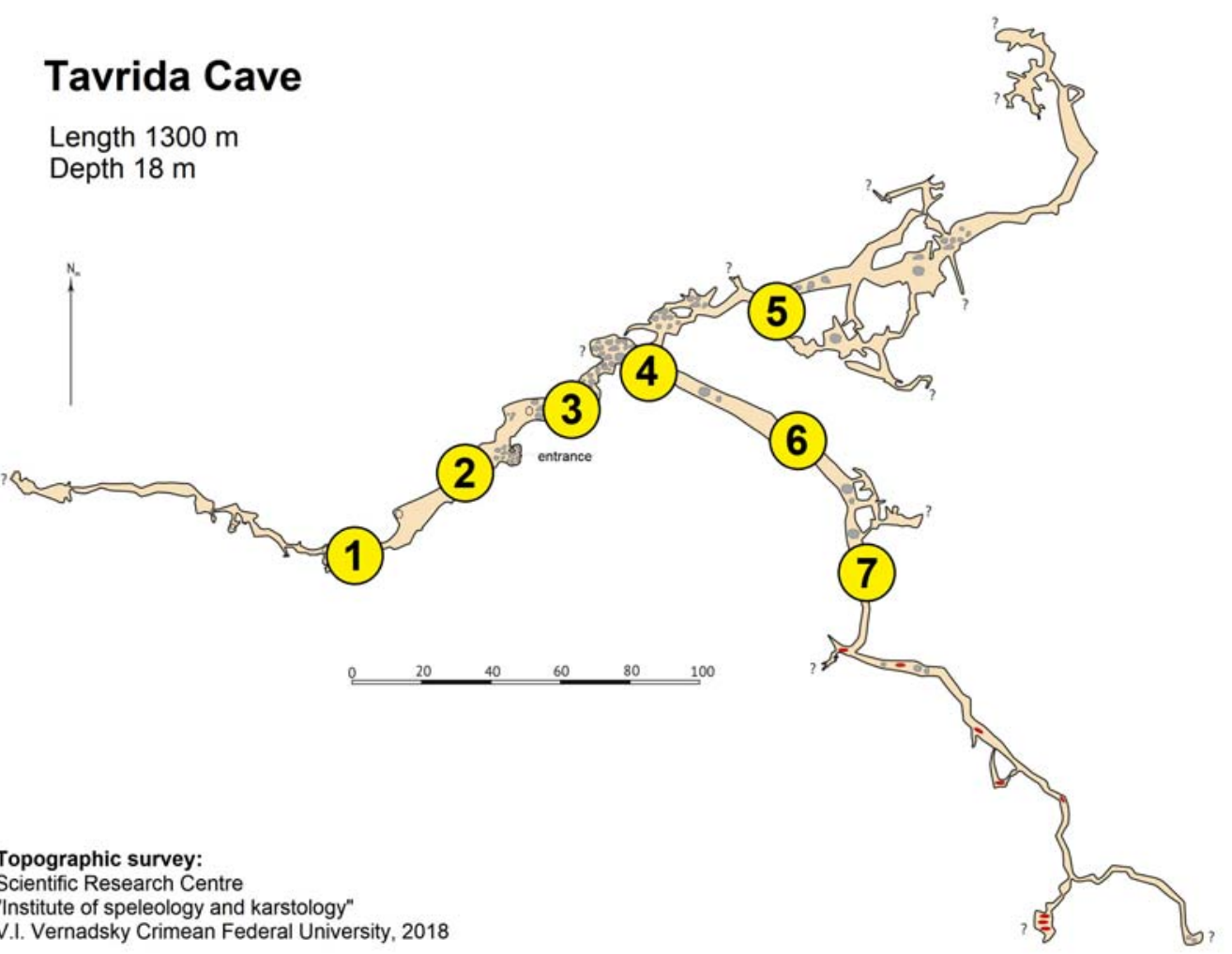

Fig. 1. The layout of biospeleological stations (yellow circles) with baits in Tavrida Cave in the period from September 28 to October 29, 2018. Topographic basis - the plan of Tavrida Cave (Amelichev et al., 2019); processing, additions and changes by I.S. Turbanov.

Рис. 1. Схема расположения биоспелеологических стационаров (желтые круги) с приманками в пещере Таврида в период с 28 сентября по 29 октября 2018 г. Топографическая основа - план пещеры Таврида (Амеличев и др., 2019); обработка, дополнения и изменения И.С. Турбанов.

Preliminary analysis and determination of the material was performed under laboratory conditions at the I.D. Papanin Institute of Inland Water Biology of the Russian Academy of Sciences (Borok, Yaroslavl Region) using a KONUS CRYSTAL 7x-45x STEREO biological stereomicroscope. For the study, the copulatory organs of the spiders were dissected, boiled in a $10 \%$ aqueous solution of potassium hydroxide $(\mathrm{KOH})$, stained with Methylenum coeruleum, and placed in glycerin on a slide with a hole. The photos of copulatory organs and spider habitus were taken at the A.O. Kovalevsky Institute of Biology of the Southern Seas of the Russian Academy of Sciences (Sevastopol) using an MBS-1 and Olympus CX41 microscopes and a
Canon EOS 550D camera attached to them. The images were processed in the Helicon Focus 7.0.2. and CorelDRAW 11 programs. The terminology of copulatory organs is given after Saaristo (1977).

Part of the material collected in Tavrida Cave was given for confirmation and/or clarification of the definition to the specialists in the relevant taxonomic groups, i.e. springtails to A.B. Babenko(A.N. Severtsov Institute of Ecology and Evolution of the Russian Academy of Sciences, Moscow, Russia), diptera to J. Roháček (Silesian Museum, Opava, Czech Republic) and A.A. Przhiboro (Zoological Institute of the Russian Academy of Sciences, St. Petersburg, Russia). 

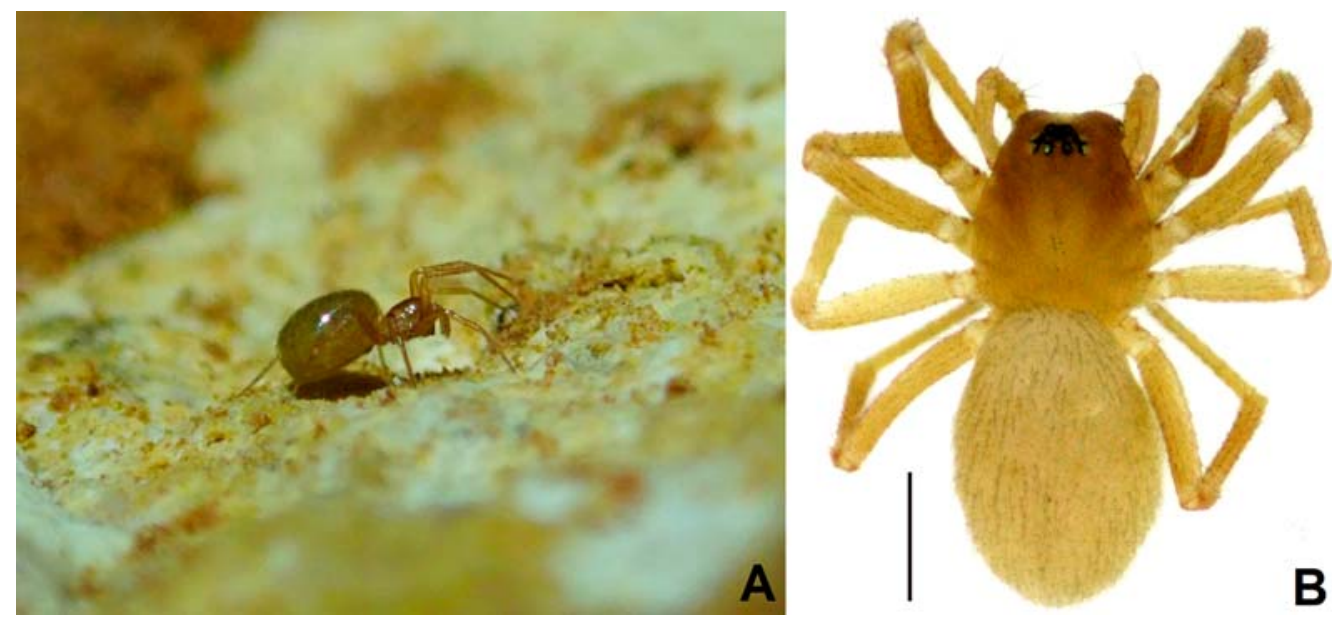

Fig. 2. Female of linyphiid spider Caviphantes dobrogicus from Tavrida Cave. A - live specimen photo in the cave (photography by I.S. Turbanov); B - habitus, dorsally, scale $0.5 \mathrm{~mm}$ (photography by A.A. Nadolny).

Рис. 2. Самка паука-линифииды Caviphantes dobrogicus из пещеры Таврида. А - прижизненная фотография в пещере (фотография И.С. Турбанова); В — габитус, дорсально, масштаб 0,5 мм (фотография А.А. Надольного).

Material examined is deposited in the $\mathrm{Na}$ tional Arachnological Collection, Tavrida Academy of V.I. Vernadsky Crimean Federal University, Simferopol (TNU), Zoological Institute of the Russian Academy of Sciences, Saint Petersburg (ZISP), A.N. Severtsov Institute of Ecology and Evolution of the Russian Academy of Sciences, Moscow (IEE), and the private collections I. Turbanov (IT).

\section{Results}

On October 29, 2018, 28 individuals of six species of invertebrates (Arthropoda) were collected in Tavrida Cave at biospeleological stations, i.e. one species of spiders (Aranei), one species of diplura (Diplura), two species of springtails (Collembola) and two species of flies (Diptera). Brief study for each of the collected species is given below.

Class Arachnida Cuvier, 1812

Order Aranei Clerck, 1758

Family Linyphiidae Blackwall, 1859

\section{Caviphantes dobrogicus (Dumitrescu et Miller, 1962) \\ Figs 2, 3.}

MATERIAL. 5 +q (TNU-10234), Crimean Peninsula, Belogorsk Distr., near Zuya, Tavrida Cave, 29.IX.2018, leg. I.S. Turbanov.

Caviphantes dobrogicus has been recorded in Bulgaria, Romania, Ukraine, Georgia, Azerbaijan, and Kyrgyzstan (Mikhailov, 2013; Polchaninova, Prokopenko, 2013; Nentwig et al., 2021). This species is recorded in the Crimea for the first time. Our discovery of $C$. dobrogicus from Tavrida Cave is the first reliable finding of this spider species in Russia. The species is considered as troglophilic (Mammola et al., 2018: Table S1). In addition to caves, it inhabits sandy steppes, sea coasts and agrocenoses (Polchaninova, Prokopenko, 2013). Since this species is a eurybiont that can enter caves, in our opinion, we characterize it as a subtroglophile.

There is only one detailed diagnostic drawing of $C$. dobrogicus epigyne in the literature (Dumitrescu, Miller, 1962). As confirmation of our finding we present photos of C. dobrogicus epigyne from Tavrida Cave (Fig. 3). The mor- 


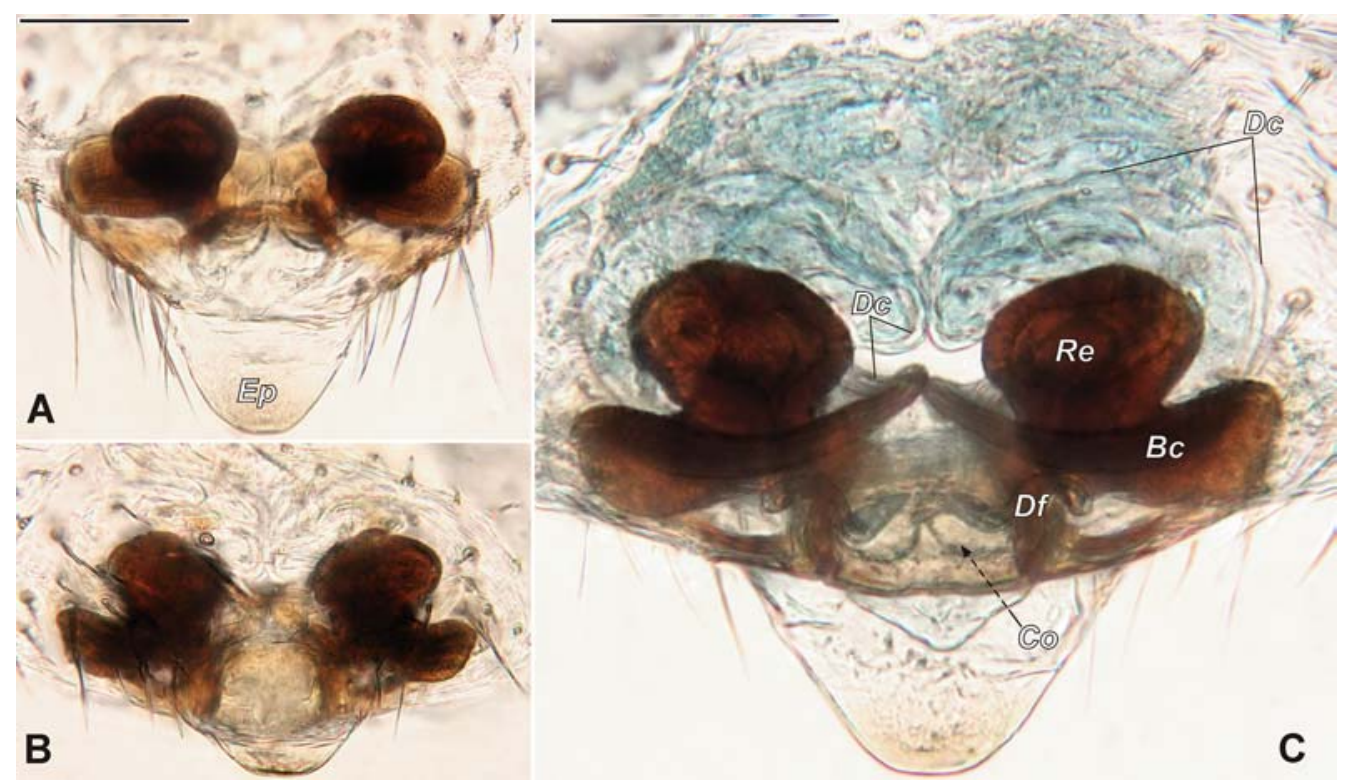

Fig. 3. Epigyne of Caviphantes dobrogicus from Tavrida Cave. A - ventral; B - ventral-caudal; C dorsal.

Abbreviations: $B c$ base of copulatory duct; $C o-$ copulatory opening; $D c-$ copulatory duct; $D f$ - fertilization duct; $E p$ - epigynal plate; $R e$ - receptacle. Scale bars $0.1 \mathrm{~mm}$ (photography A.A. Nadolny).

Рис. 3. Эпигина паука Caviphantes dobrogicus из пещеры Таврида. А — вентрально; В — вентральнокаудально; С - дорсально.

Обозначения: $B c-$ основание копулятивного канала; $C o-$ копулятивное отверстие; $D c-$ копулятивный канал; $D f$ - оплодотворительный канал; $E p$ - пластинка эпигины; $R e-$ рецептакула. Масштаб 0,1 мм (фотографии А.А. Надольного).

phological features of our specimens correspond to the description of C. dobrogicus (Dumitrescu, Miller, 1962): the epigynal plate (Ep) has a shape of a tongue; the copulatory openings (Co) are located at the base of the epigynal plate; copulatory ducts $(D c)$ are long, convoluted, their walls are thin, membranous, slightly sclerotized, except the base of the copulatory ducts $(B c)$ - thickened and well sclerotized; the receptacles $(R e)$ are oval, sclerotized; the receptacula is joined with the copulatory and fertilization ducts posteriorly.

However, the proportions of some parts of the epigyne of the spiders from Tavrida Cave differ from those in the original description of C. dobrogicus. In particular, the epigynal plate of the spiders from Tavrida Cave is narrower but the distance between the lateral edges of the base of the copulatory ducts and the receptacula is greater. We believe that such differences should not be interpreted as sufficient to describe a new species. To clarify this case, we need males from the cave, as well as comparative material from different parts of the range of C. dobrogicus.

Class Entognatha Stummer-Traunfels, 1891

Order Diplura Börner, 1904

Family Campodeidae Meinert, 1865

Campodea (Dicampa) taurica Silvestri, 1949 Fig. 4.

MATERIAL. $1 \bigcirc^{\gamma}, 1 q$ (IT), Crimean Peninsula, Belogorsk Distr., near Zuya, Tavrida Cave, 29.IX.2018, leg. I.S. Turbanov.

Campodea (Dicampa) taurica troglobiont diplura, endemic to caves of the Crimea. For the first time it was presented in the work of V.G. Pliginsky (1927) from the Kizil-Koba (=Kras- 


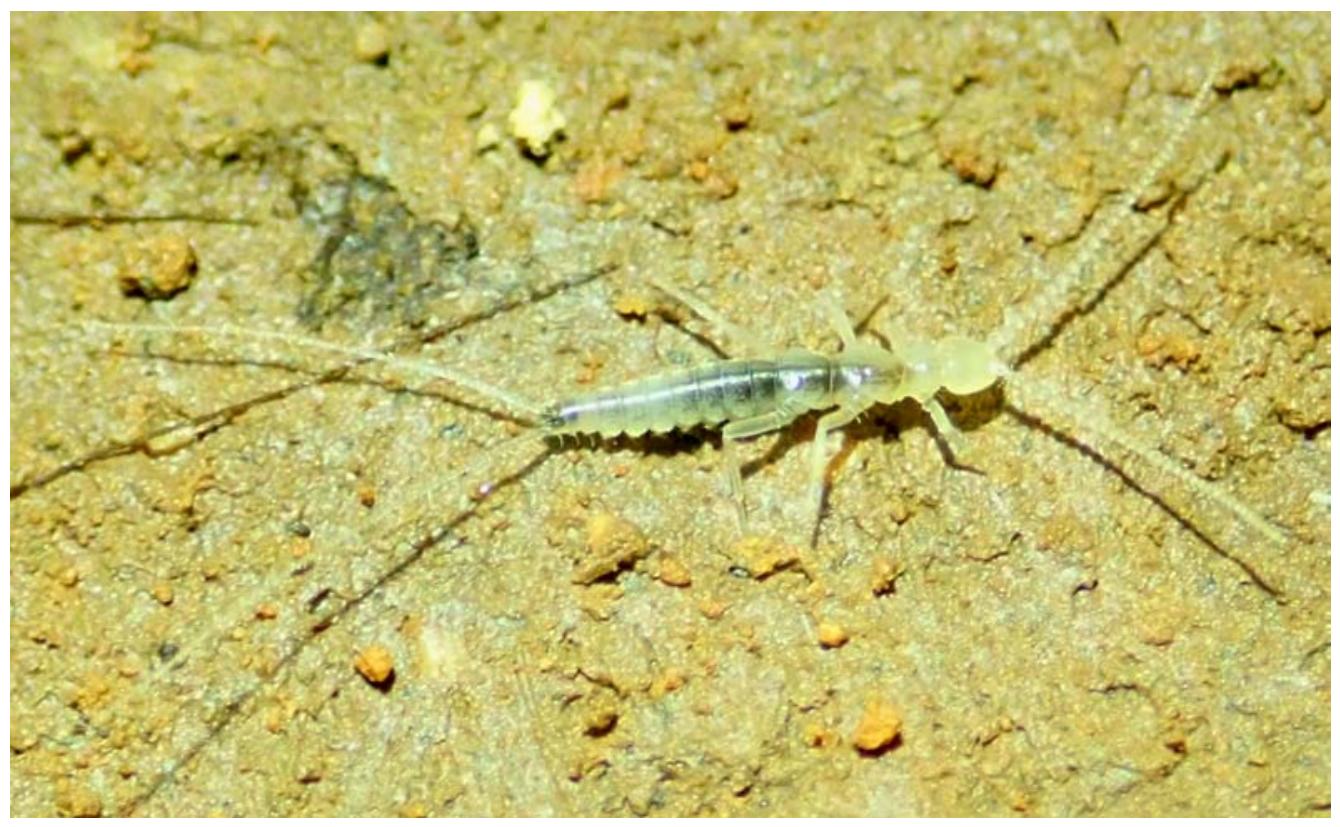

Fig. 4. Live specimen photo diplura Campodea (Dicampa) taurica in Tavrida Cave (photography by I.S. Turbanov).

Рис. 4. Прижизненная фотография диплюры Campodea (Dicampa) taurica в пещере Таврида (фотография И.С. Турбанова).

naya) Cave (Dolgorukovsky karst massif) but the species itself was described much later (Silvestri, 1949). There is a record of C. (D.) cf. taurica in Mangupskaya I Cave (Bakhchisarai karst massif) (Turbanov, 2018). In addition, our collections contain material from a number of caves in the Ai-Petri and Karabi karst massifs (unpublished data).

Class Collembola Lubbock, 1870

Order Entomobryomorha Börner, 1916, sensu Soto-Adames et al., 2008

Family Entomobryidae Schäffer, 1896, sensu Zhang et al., 2015

\section{Pseudosinella aff. immaculata} (Lie-Pettersen, 1896)

MATERIAL. 1 ex. (IEE), 10 exx. (IT), Crimean Peninsula, Belogorsk Distr., near Zuya, Tavrida Cave, 29.IX.2018, leg. I.S. Turbanov.

A Western Palearctic species, widely spread in Europe and North Africa. It inhabits nemoral forests and meadow-to-steppe biotopes. It lives in the soil, litter, under rocks, in rodent burrows and in caves (Kaprus' et al., 2006).

We consider this species to be subtroglophilic. In the literature, we have not found reliable indications for the detection of Pseudosinella aff. immaculata on the territory of the Crimean Peninsula.

Order Poduromorpha Bцrner, 1913, sensu D'Haese, 2002

Family Hypogastruridae Börner, 1906

Schoettella ununguiculata (Tullberg, 1869)

MATERIAL. $1 \sigma^{\top}, 1$, 1 juv. (IEE), Crimean Peninsula, Belogorsk Distr., near Zuya, Tavrida Cave, 29.IX.2018, leg. I.S. Turbanov.

A widespread Holarctic species of Collembola (Babenko, 1994). Specimens from Tavrida Cave, as well as previously recorded for the Crimean Mountains (Babenko, 1994), have characteristic large three-lobed apical papillae on 
the antennae and longer and coarser dorsal chaetes.

This species belongs to the eurybionts which inhabits different forest, meadow, steppe and near-water biotops, penetrates into caves, anthropogenic environments (Kaprus' et al., 2006). We consider this species to be subtroglophilic.

Class Insecta Linnaeus, 1758

Order Diptera Linnaeus, 1758

Family Sphaeroceridae Macquart, 1835

\section{Terrilimosina racovitzai (Bezzi, 1911)}

MATERIAL. 5 ○ $\sigma^{7}$ (ZISP), Crimean Peninsula, Belogorsk Distr., near Zuya, Tavrida Cave, 29.IX.2018, leg. I.S. Turbanov.

A widespread Holarctic species, i.e. Canada, Afghanistan, most of Europe, and southern Russia (Marshall et al., 2011). In the literature, we have not found any reliable indications of the presence of Terrilimosina racovitzai on the territory of the Crimean Peninsula.

Within its range, $T$. racovitzai has been recorded in a number of terrestrial ecosystems as well as in burrows and caves. Troglophilic species (Roháček, 1982).

Sphaeroceridae sp. indet.

MATERIAL. 2 puparia (ZISP), Crimean Peninsula, Belogorsk Distr., near Zuya, Tavrida Cave, 29.IX.2018, leg. I.S. Turbanov.

Near the baits (hard cheese pieces), we found two puparia (larval skin (exuvium) of an adult larva, containing a pupa), not identified to the species of diptera of the family Sphaeroceridae Macquart, 1835. Regarding the identification of the species, we received the comments from dipterologist J. Roháèek. In his opinion, the puparia found together with the imago Terrilimosina racovitzai certainly do not belong to the latter species, since they are too large. Because of their short, fingered forelimb and size, they may have belonged to other species of family Sphaeroceridae, such as Herniosina Roháèek, 1983, or Limosina Macquart, 1835, or even to some smaller species of subfamily Copromyzinae Stenhammar, 1855.
There is no doubt that puparia belong to a species that is not a specialized cave inhabitant (troglobiont), since its imago (adults) were attracted to bait (cheese) near the entrance part at station No. 2 (see Fig. 1), where they laid eggs, and subsequently the larvae completed development and pupated.

\section{Discussion}

The preliminary results show young age of recent fauna of Tavrida Cave (despite its Eopleistocene age) with no ancient troglobiont forms. However, the troglobiont diplura Campodea (Dicampa) taurica, whose origin is associated with the Late Pleistocene time, should be discussed closer.

Wide distribution of troglobiont diplura C. (D.) taurica in Tavrida Cave and a number of other unrelated karst cavities of the Mountainous and Foothill Crimea, is most likely associated with the geological history of the peninsula. In the Pliocene-Early Pleistocene period, as the Mountain-Crimean Karst Region (Main Ridge) was freed from the Cretaceous-Paleogene cover (Vakhrushev, 2001; Lysenko, 2002) and the orographic separation of the FoothillCrimean Karst Region (Inner and Outer Ridges) in the Middle and Late Pleistocene (Vakhrushev, 2001; Klimchouk et al., 2013), the caves got inhabited by the ancestral soil form of this species. At the same time, there was no subsequent allopatric speciation in isolated populations. This point of view is consistent with the ideas about the geological history and age of the karst of the Crimean Peninsula (Vakhrushev, 2001, 2010; Muratov, 1960) and could confirms the opinion expressed about the Pleistocene age of the troglobiont fauna (Prokopov, Turbanov, 2017).

All the other above-mentioned species are not specialized inhabitants of Tavrida Cave, most likely they are geobionts or inhabitants of MSS-biotopes (near-surface cavernous zone), but at the same time they successfully penetrate into caves. The troglophilic species, namely linyphiid spider C. dobrogicus, springtails $P$ seudosinella aff. immaculata, Schoettella unun- 
guiculata, and flies Terrilimosina racovitzai, Sphaeroceridae sp. indet., most likely occupied this karst cavity through an artificial entrance.

Despite the small amount of data obtained on the biota of Tavrida Cave, these results have a significant faunal value. For the first time, such species as springtail $P$. aff. immaculata, fly $T$. racovitzai and spider C. dobrogicus are recorded in the fauna of the Crimea; the latter species is listed for the first time in the fauna of Russia. For the first time, C. dobrogicus, $P$. aff. immaculata, S. ununguiculata, and T. racovitzai are found in the caves of the Crimea. The finding of troglobiont diplura $C$. (D.) taurica in Tavrida Cave add to the knowledge about its range in the Crimea.

\section{Compliance with ethical standards}

CONFLICTS OF INTEREST: The authors declare that they have no conflicts of interest.

Acknowledgments. The authors express their sincere gratitude to: G.V. Samokhin and S.V. Tokarev (Tavrida Academy of the V.I. Vernadsky Crimean Federal University, Simferopol, Russia) for their assistance while collecting materials in Tavrida Cave; A.B. Babenko (A.N. Severtsov Institute of Ecology and Evolution of the Russian Academy of Sciences, Moscow, Russia), J. Roháček (Silesia Museum, Opava, Czech Republic) and A.A. Przhiboro (Zoological Institute of the Russian Academy of Sciences, St. Petersburg, Russia) for their help in determining and identifying the arthropods collected; A.G. Koval (All-Russian Research Institute of Plant Protection, Saint Petersburg, Russia) for editing and commenting on an early draft; D.M. Palatov (A.N. Severtsov Institute of Ecology and Evolution of the Russian Academy of Sciences, Moscow, Russia) for reviewing the article; N.V. Ashchepkova (Civo SO, Italy) for improving the English language of the manuscript. This study was performed in the framework of the state assignment: Ilya S. Turbanov (topics Nos AAAAA 18-118012690106-7, AAAAA-A18118012690105-0) and Anton A. Nadolny (topic No. AAAAA 18-118020890074-2).

\section{References}

Amelichev G.N., Tokarev S.V., Samokhin G.V., Vakhrushev B.A., Startsev D.B. 2018. [Karstological and speleological materials of preliminary survey of Tavrida Cave (Piedmont Crimea)] // Izucheniye i ispolzovaniye estestvennykh $\mathrm{i}$ iskusstvennykh podzemnykh prostranstv i zakarstovannykh territoriy. Materialy Vserossiyskoy nauchno-prakticheskoy konferentsii II Krymskiye karstologicheskiye chteniya. 25-28 September 2018, Simferopol. Simferopol: (s. n.). P.191196 [in Russian, with English summary].

Amelichev G.N., Tokarev S.V., Samokhin G.V. 2019. [Tavrida Cave] // Atlas peshcher Rossii. Moscow: (s. n.). P.214-216 [in Russian].

Babenko A.B. 1994. [Genus Schoettella Schäffer, 1896] // Opredelitel kollembol fauny Rossii i sopredelnykh stran. Semeistvo Hypogastruridae. Moscow: Nauka. P.195-197 [in Russian].

Dumitrescu M., Miller F. 1962. Lessertiella dobrogica n. gen. n. sp. Arraignée endémique de la grotte «Peştera Liliecilor dela Gura Dobrogei» (Aranea) // Časopis Československé Společnosti Entomologické. Vol.59. No.2. P.165-173.

Kaprus' I.J., Shrubovych J.J., Tarashchuk M.V. 2006. [Catalogue of the Collembola and Protura of Ukraine]. Lvov: (s. n.). 164 p. [In Ukrainian]

Klimchouk A.B., Amelichev G.N., Vakhrushev B.A. Samokhin G.V. 2009. [From marine and glacial isotope scales to speleothem chronology of paleoclimatic events] // Geopolitika i ekogeodinamika regionov. Vol.5. No.1. P.44-51 [in Russian].

Klimchouk A.B., Tymokhina E.I., Amelichev G.N., Dublyansky Y.V., Spötl C. 2013. [The hypogene karst of the Crimean Piedmont and its geomorphological role]. Simferopol: DIP. 204 p. [In Russian]

Lopatin A.V., Vislobokova I.A., Lavrov A.V., Startsev D.B., Gimranov D.O., Zelenkov N.V., Maschenko E.N., Sotnikova M.V., Tarasenko K.K., Titov V.V. 2019. [Taurida Cave, a new locality of the Early Pleistocene vertebrates in Crimea] // Doklady Ross. Akademii nauk. Vol.485. No.3. P.381-385 [in Russian, with English summary].

Lysenko N.I. 2002. [On a new find of Lower Cretaceous deposits at the Crimean yaila] // Priroda. No.1 P.2-4 [in Russian].

Marshall S.A., Roháček J., Dong H., Buck M. 2011. The state of Sphaeroceridae (Diptera: Acalyptratae): a world catalog update covering the years 2000-2010, with new generic synonymy, new combinations, and new distributions // Acta Entomologica Musei Nationalis Pragae. Vol.51. No.1. P.217-298.

Mammola S., Cardoso P., Ribera C., Pavlek M., Isaia M. 2018. A synthesis on cave-dwelling spiders in Europe // Journal of Zoological Systematics and Evolutionary Research. Vol.56. No.1. P.301-316.

Mikhailov K.G. 2013. The spiders (Arachnida: Aranei) of Russia and adjacent countries: a non-annotated checklist. Moscow: KMK Scientific Press. 262 p. (Arthropoda Selecta, Supplement No.3). 
Muratov V.V. 1960 [A brief sketch of the geological structure of the Crimean Peninsula]. Moscow: Gosudarstvennoye nauchno-tekhnicheskoye izdatelstvo literatury po geologii i okhrane nedr. 208 p. [In Russian]

Nentwig W., Blick T., Gloor D., Hanggi A., Kropf C. 2021. Spiders of Europe. Version 01. Available online: www.araneae.unibe.ch. (Accessed: 27.01.2021).

Pliginsky V.G. 1927. [On the fauna of Crimean caves. III] // Entomologicheskoe Obozrenie. Vol.21. Nos 3-4. P.171-180 [in Russian, with English summary].

Polchaninova N.Yu., Prokopenko E.V. 2013. Catalogue of the spiders (Arachnida, Aranei) of Left-Bank Ukraine. Moscow: KMK Scientific Press. 268 p. (Arthropoda Selecta, Supplement No.2).

Prokopov G.A., Turbanov I.S. 2017. [To the question of speleofauna formation in the Crimean Peninsula] // Biospeleologicheskie issledovanya v Rossii i sopredel'nykh gosudarstvakh. Materialy II Vserossiyskoi molodezhnoi konferentsii. December 1-2, Moscow. Yaroslavl: Filigran. P.99-106 [in Russian, with English summary].

Roháček J. 1982. A monograph and re-classification of the previous genus Limosina Macquart (Diptera, Sphaeroceridae) of Europe. Part I // Beiträge zur Entomologie. Vol.32. No.2. P.195-282.

Saaristo M.I. 1977. Secondary genital organs in the taxonomy of Lepthyphantinae (Araneae, Linyphiidae) //
Reports from the Department of Zoology, University of Turku. No.5. P.1-16.

Silvestri F. 1949. Descrizione di due specie nuove cavernicole di Campodeidae (Insecta: Diplura) della regione Monte Tauro // Bollettino del Laboratorio di Entomologia Agraria, Portici. Vol.9. P.27-31.

Turbanov I.S. 2018. [To the knowledge of the hypogenous fauna of the Baba-Dagh outlier massif and its significance in the biospeleological zoning of the Crimea] // Izucheniye $\mathrm{i}$ ispolzovaniye estestvennykh $\mathrm{i}$ iskusstvennykh podzemnykh prostranstv i zakarstovannykh territoriy. Materialy Vserossiyskoy nauchno-prakticheskoy konferentsii II Krymskiye karstologicheskiye chteniya. 25-28 September, Simferopol. Simferopol: (s. n.). P.152-157 [in Russian, with English summary]. Vakhrushev B.A. 2001. [Paleogeography of the Crimea in the light of the latest karstological and speleological studies] // Kul'tura narodov Prichernomoria. Vol.17. P.11-18 [in Russian].

Vakhrushev B.A. 2009. [Regionalization of karst of the Crimean Peninsula] // Speleologiya i Karstologiya. Vol.3. P.39-46 [in Russian, with English and Ukrainian summary].

Vakhrushev B.A. 2010. [Crimean Mountains] // Reli'ef Ukrainy. Kiev: Slovo. P.432-485 [in Ukrainian].

Responsible editor K.G. Mikhailov 